\title{
Learning Style Responses to an Online Soil Erosion Lesson
}

\author{
Martha Mamo,* Timothy Kettler, and Dann Husmann
}

\begin{abstract}
Our objective was to evaluate responses from students with different learning styles to the use of computer technology as a supplemental tool in teaching soil erosion concepts. The online lesson utilized photographs, illustrations, animations, and an interactive model that allowed students to manipulate factors influencing soil erosion. Students $(n=52)$ were given 10 objective pre-test questions before the lesson and 10 objective post-test questions after lesson completion. Students completed the Student Assessment of Learning Gains (SALG) and Kolb Learning Style Inventory (KLSI) within a week of concluding the lesson. The SALG instrument is an assessment tool used by faculty to ask students a variety of questions related to their gains in learning and KLSI is used to assess a student's preference in acquiring new knowledge and/or skills. Performance on the pre- and post-tests and SALG responses were compared among students. Among the online lesson participants who completed the KLSI, $22,29,24$, and $25 \%$ were divergers, accommodators, convergers, or assimilators, respectively. Pre-test and post-test scores ranged from 6.1 to 7.4 and 6.6 to 7.3, respectively. Accommodators had the lowest pre-test scores among the learning styles; however, there were no differences in post-test scores among learning styles. Responses to the 43 SALG questions which encompassed the areas of lesson design, skill gains, learning gains, and understanding were similar among the learning styles. This study suggests that with proper instructional design, online lessons can be used to broaden the range of available teaching tools and increase learning among students of all learning styles.
\end{abstract}

$\mathrm{U}$ SE OF COMPUTER TECHNOLOGY is becoming widespread in college classrooms as a teaching tool. A 1995 survey by the U.S. Department of Education (1995) estimated that $84 \%$ of all higher education institutions use computer-based technology in their distance education courses. Research by Donaldson et al. (1999) shows that students are becoming increasingly proficient in utilizing computers as educational tools in the university setting.

Learning theory suggests that Internet-based courses may be differentially attractive to students depending upon their learning styles (Felder and Solomon, 1999). Learning styles are indicators of how learners perceive, interact with, and respond to the learning environment (DeBello, 1990). Frederico (2000) used KLSI and observed that students with assimilating and accommodating learning styles demonstrated higher positive attitudes toward design of network-based instructions compared with students with converging and di-

M. Mamo and T. Kettler, Dep. of Agronomy and Horticulture, Univ. of Nebraska, Lincoln, NE 68583; and D. Husmann, Dep. of Agricultural Leadership, Education and Communication, Univ. of Nebraska, Lincoln, NE 68583. Journal Series no. 04-06 of the Univ. of Nebraska College of Agric. Sciences and Natural Resources, Lincoln, NE 68583. Article. *Corresponding author (mmamo3@unl.edu).

Published in J. Nat. Resour. Life Sci. Educ. 34:44-48 (2005). http://www.JNRLSE.org

(C) American Society of Agronomy

677 S. Segoe Rd., Madison, WI 53711 USA verging learning styles. Ellsworth (1995) found that among users of computer-aided instructions, students who are active experimentators and reflective observers preferred computeraided instruction because of the ability to control their own learning. Doherty and Maddux (2002), using the Index of Learning Styles on 71 distance education courses, found that global learners (e.g, like to learn in "big picture") were less likely to complete Internet-based courses than sequential learners (e.g, like to learn in steps or pieces).

The KLSI is based on how a person prefers to acquire new knowledge and/or skills (Kolb, 1976). Learners have two preferences for dealing with information: (i) concrete experience (CE) or abstract conceptualization (AC), and (ii) active experimentation (AE) or reflective observation (RO). The combination of these preferences leads to four learning modes or classifications:

- A Type I learner (CE and RO), or diverger, often focuses on the why question (Felder, 1996). A Type I learner likes imaginative and innovative activities, generates a wide range of ideas, discusses, is sensitive to feelings, identifies problems and gathers information, is personally involved in the learning experience, and likes group activities. The learner may enjoy independent study, web searches, receiving many examples, and self-diagnostic activities (Felder, 1996).

- A Type II learner (CE and AE), or accommodator, often focuses on the what if questions (Felder, 1996). A Type II learner likes to connect what he/she is learning into the context of real world problems. This learner likes hands-on experience, active learning, carrying out solutions, risk taking, trial and error, flexibility, sharing information with others, class discussion, debates, presentations, and group activities. The Type II learner dislikes structure and authority figures. He or she works well with others and/or serving as a leader. This learner may enjoy role play, narration, and online peer interaction (Felder, 1996).

- A Type III learner (AC and AE), or converger, often focuses on the how question (Felder, 1996). A Type III learner finds practical uses for ideas and theories, evaluates consequences and selects solutions, follows detailed sequential steps, and enjoys hands-on activities, trial and error, and being given clear objectives with a logical sequence to activities. This learner does not do as well in interpersonal situations. He or she may enjoy simulations, selecting information sources, guest speakers, and practical application.

- A Type IV learner (AC and RO), or assimilator, often focuses on the what question (Felder, 1996). A Type IV learner likes abstract ideas and concepts, creates conceptual models, designs experiments, solves problems, considers alternative solutions, reads, reflects, theorizes, analyzes quantitative information, and likes structured activities. The

Abbreviations: AC, abstract conceptualization; AE, active experimentation; CE, concrete experience; KLSI, Kolb learning style inventory; RO, reflective observation; SALG, student assessment learning gain; T, erosion tolerance level; USLE, universal soil loss equation. 
learner may enjoy a systematic approach, detailed directions, and computer-assisted instruction (Felder, 1996).

The objective of this study was to evaluate learner's attitudes toward an online lesson in soil science. A web-based interactive soil erosion lesson was developed, implemented into an introductory soil science course, and assessed for its usefulness in the classroom. Our hypothesis was that the addition of interactive online lessons in soil science will stimulate similar attitudes among different learners.

\section{MATERIALS AND METHODS}

Soil erosion was the 16th of 21 lessons presented to students in an introductory soil sciences course in the fall of 2001. The overall objective of the lesson was to enhance student learning on the causes of soil erosion, environmental degradation that results from erosion, and soil management practices that can be implemented to prevent and mitigate erosion's occurrence.

Before completing the online lesson, students were assigned readings from the course textbook and asked to complete a supplementary study outline over the material. Each student took a pre-test based on assigned readings for the lesson. After the pre-test, students received a 45-minute lecture covering the topic of soil erosion, its causes, and control.

The content of the soil erosion online lesson was created based on 13 specific learning objectives. The online lesson had 13 pages of text, 17 photos, 8 figures, 1 table, 1 animation, and 1 interactive modeling program (Fig. 1). Lesson animation showed the wind erosion process, depicting small and large soil particle movement caused by wind (Fig. 1). A quantitative soil erosion prediction model based on the Universal Soil Loss Equation (USLE) was adapted from Kansas State University (Thien, 1999) and was used as an interactive learning resource at the end of the lesson. Interacting with the USLE model allowed students to manipulate relevant variables such as soil type, climate, residue cover, and cropping system; and assess the effects of different soil management strategies on predicted soil erosion loss (Fig. 1).

Working individually, each one of 52 students completed the online lesson during 2-hour periods in a computer/lab type classroom. The instructor was available while they worked to answer both content and computer related questions. As students worked on the lesson, they completed a worksheet consisting of 11 questions addressing mechanisms of water and wind erosion, factors controlling erosion, and management measures for erosion (Fig. 2). The last worksheet question described a field scenario where the management practice was eroding soil above the erosion tolerance level $(T)$ of $11.2 \mathrm{Mg}$ $\mathrm{ha}^{-1}$. Using the USLE program, students first evaluated the amount of soil loss from the current field scenario. Then, students manipulated the relevant variables until they obtained a management plan that resulted in a soil loss rate less than $T$.

A post-test was administered to students immediately after completing the online lesson. Both the pre-tests and posttests consisted of 10 multiple choice questions created to address the learning objectives of the lesson. Within 1 week after completing the lesson, students completed both the SALG adapted from Seymour (1997) and the KLSI (Kolb, 1976).

The SALG instrument is an assessment tool used by faculty to ask students a variety of questions related to their gains in learning. Through an online survey, students are asked to select statements of agreement or disagreement in relation to skills development, cognition, and their attitude toward the subject being studied within the course (Seymour, 1997). The survey included six categories which students rated on a 1 to 5 Likert-type scale ( $5=$ best, $1=$ worst). A Cronbach alpha level of 0.97 validated the reliability of the instrument (Gravetter and Wallnau, 1996).

The KLSI, described above, is an instrument that categorizes student's learning style. The student is presented with 12 phrases, each with responses designed to identify how the student learns and deals with ideas and day-to-day situations in everyday life. The student ranks the responses from 1 to 4 (4 $=$ most like, and 1 = least like the student) based upon how he/she sees himself/herself as a learner. The rankings for each response category are totaled and used to create a score used to place the student in 1 of 4 learning style categories.

\section{Statistical Analyses}

Differences among the learning styles in the 43 SALG responses were compared by PROC GLM procedure on SAS, version 8 (SAS Institute, 1999). Test scores among the learning styles were compared by mixed model analysis using PROC MIXED procedure on SAS, version 8 (SAS Institute, 1999). Student was set as a random effects and learning style, pre-test, and post-test were fixed effects (Littell et al., 1999). Least significant differences (LSD) among learning styles for pre- or post-tests were significant at the 0.10 probability level.

\section{RESULTS AND DISCUSSION}

Among the 52 online lesson participants who completed the KLSI, 22\% were Type I learners (divergers), 29\% were Type II learners (accommodators), 24\% were Type III learners (convergers), and 25\% were Type IV learners (assimilators). Accommodators had lower pre-test scores compared with the other learning styles (Table 1). Accommodators learn or perceive concepts through hands-on experience and link the concepts into real world problems. The assigned textbook readings and study outlines used in preparation for the pre-test may not have been sufficiently meaningful to real-world situations. Accomodators may be at a disadvantage if the method of teaching relies heavily on textbook reading with minimal real-world application activities. However, post-test scores were similar among learning styles, suggesting that the online erosion presentation helped to reinforce the concepts of soil erosion by accommodating all learning styles. Pre-test and post-test scores were similar within each learning style category. Mean responses to the 43 SALG questions were similar among the different learning styles in all six categories (Table 2). Student satisfaction, as measured by SALG ratings, has also been demonstrated to be better with students completing the online lesson compared with students using the traditional paper and pencil worksheet method (Mamo et al., 2004). Each learning style had agreeable responses on the design of the online lesson (Questions 1-8). Specifically, each learning style agreed on the working pace (i.e., not being rushed by group members) of the online lesson. Also, lesson participation ratings among learning styles were similar. Unlike this study, Frederico (2000) found assimilators to be more satisfied with network-based instruction. This suggests that the 

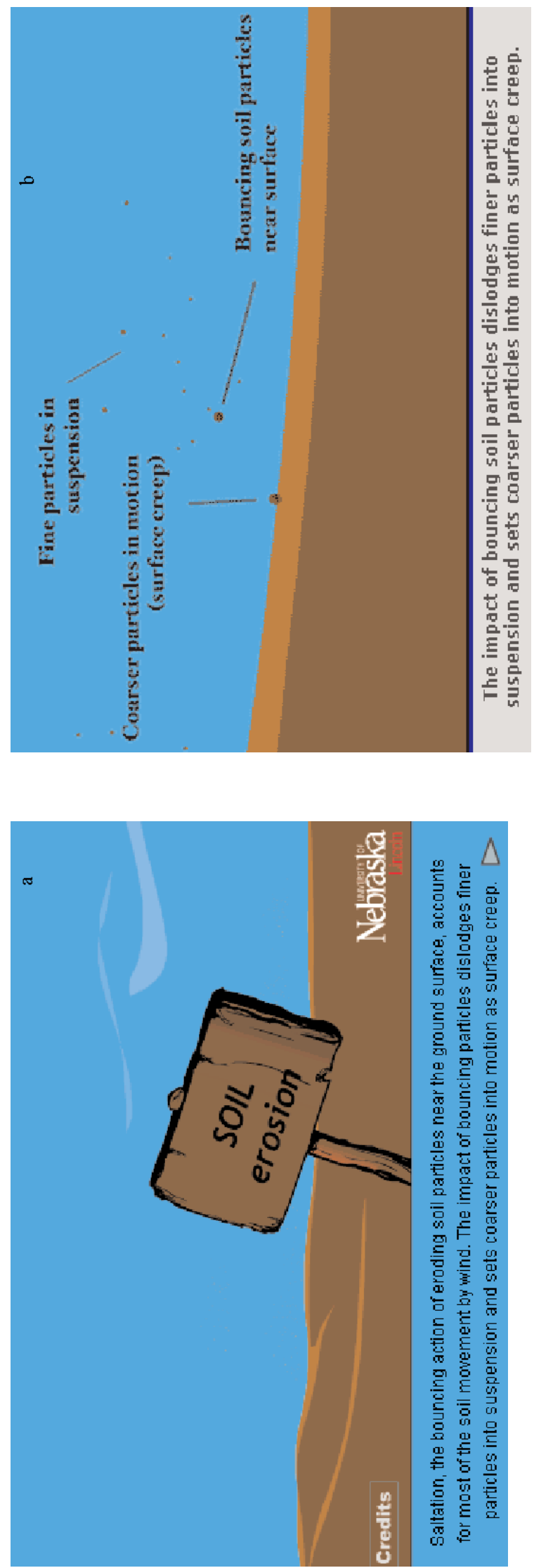

Fig. 1. Screen shots of pages $(a, b)$ on wind erosion animation and (c) rainfall (R) factor selection page of the Universal Soil Loss Equation interactive model.

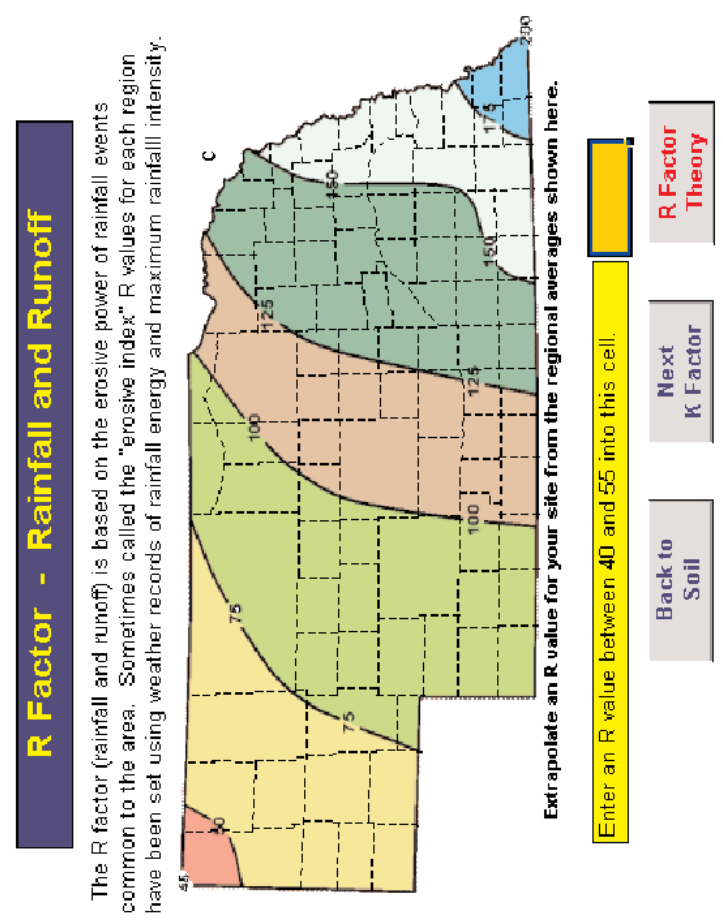

Fig. 2. Exercise worksheet assigned to Introductory Soil Science students who completed the online erosion lesson. 
Table 1. Test score (out of possible 10 points) comparison among student learning styles on Soil Erosion online lesson in an Introductory Soil Science course.

\begin{tabular}{lccc}
\hline Kolb learning style & $\begin{array}{c}\text { Pre-test } \\
\text { mean score }\end{array}$ & $\begin{array}{c}\text { Post-test } \\
\text { mean score }\end{array}$ & LSD $(0.1) \dagger$ \\
\hline Diverger & 7.3 & 7.3 & 0.9 \\
Accomodator & 6.1 & 6.6 & 0.9 \\
Converger & 7.4 & 7.3 & 1.3 \\
Assimilator & 7.2 & 7.1 & 0.9 \\
$\quad$ LSD $(0.1) \neq$ & 0.5 & 1.2 & \\
\hline
\end{tabular}

$\dagger$ LSD, least significant difference at the 0.1 probability level within a row.

$\$$ LSD, least significant difference at the 0.1 probability level within a column. design of the online lesson was helpful to all styles of learners, not just assimilating and accommodating learning styles. Differences between this study and that of Frederico (2000) may be due to difference in instructional design and the way it was used (i.e., used as an additional teaching tool and not as the only tool).

With regard to 'availability of resources to help in students' learning' (Questions 9-18), responses were similar among learning styles. In particular, students with different learning styles had similar perception in skills of estimating soil erosion using the USLE (Question 17). The quantitative interac-

Table 2. Summary of results of Student Assessment of Learning Gains (SALG) survey comparing student learning style on an online lesson in an Introductory Soil Science course.

\begin{tabular}{|c|c|c|c|c|c|}
\hline \multirow[b]{2}{*}{ Question } & \multicolumn{4}{|c|}{ Learning style types $\dagger$} & \multirow[b]{2}{*}{$P>F \ddagger$} \\
\hline & I & II & III & IV & \\
\hline \multicolumn{6}{|l|}{ How much did each of the following aspects help your learning? } \\
\hline 1. The way in which the material was approached. & 3.64 & 3.93 & 3.58 & 3.77 & 0.68 \\
\hline 2. The pace at which we worked. & 3.36 & 3.73 & 3.92 & 3.77 & 0.52 \\
\hline 3. Ability to proceed through section of the lesson. & 3.64 & 3.73 & 4.00 & 4.38 & 0.26 \\
\hline 4. Participation in the lesson and preparation for the test. & 3.82 & 4.13 & 3.17 & 4.08 & 0.15 \\
\hline 5. The fairness of test content as related to erosion. & 4.09 & 4.27 & 3.33 & 3.77 & 0.49 \\
\hline 6. The mental stretch required to complete the lesson. & 3.73 & 4.13 & 3.30 & 3.77 & 0.58 \\
\hline 7. The grading system used in this lesson. & 3.82 & 4.47 & 3.08 & 3.84 & 0.18 \\
\hline 8. The feedback received from this lesson. & 4.09 & 4.07 & 3.00 & 3.69 & 0.36 \\
\hline \multicolumn{6}{|l|}{ How much did resources provided help your learning with respect to the following: } \\
\hline 9. The overall cause of erosion. & 4.18 & 3.80 & 4.00 & 4.23 & 0.36 \\
\hline 10. The impact of water on erosion. & 4.18 & 4.00 & 4.08 & 4.15 & 0.92 \\
\hline 11. The water erosion process. & 4.18 & 4.07 & 4.92 & 4.23 & 0.73 \\
\hline 12. The impact of wind on erosion. & 4.09 & 3.73 & 3.67 & 4.08 & 0.57 \\
\hline 13. Understanding the factors effecting wind erosion. & 4.09 & 3.67 & 3.75 & 4.23 & 0.40 \\
\hline 14. Understanding the control of wind erosion. & 3.91 & 3.67 & 3.75 & 3.62 & 0.91 \\
\hline 15. The effects of erosion. & 4.00 & 3.87 & 3.83 & 4.23 & 0.65 \\
\hline 16. Understanding the factors enhancing soil erosion. & 4.54 & 3.80 & 3.83 & 4.23 & 0.36 \\
\hline 17. Estimating soil erosion from fields using USLE. & 4.00 & 4.07 & 4.00 & 4.08 & 0.99 \\
\hline 18. The overall perception of this lesson on erosion. & 4.27 & 3.93 & 4.00 & 4.23 & 0.87 \\
\hline \multicolumn{6}{|l|}{ How much did information you were given about this lesson help your learning? } \\
\hline 19. Preparation for the erosion lesson. & 3.09 & 3.87 & 3.08 & 3.54 & 0.28 \\
\hline 20. The teacher provided support for this module on erosion. & 4.27 & 3.60 & 3.75 & 3.69 & 0.58 \\
\hline \multicolumn{6}{|l|}{ Because of the lesson, how well do you think you now understand each of the following? } \\
\hline 21. Ability to differentiate between geologic and accelerated erosion. & 4.00 & 3.87 & 3.92 & 4.46 & 0.22 \\
\hline 22. Ability to describe the mechanisms of soil erosion. & 3.64 & 3.73 & 3.83 & 4.38 & 0.27 \\
\hline 23. Ability to describe four types of water erosion. & 3.82 & 3.87 & 3.75 & 3.62 & 0.89 \\
\hline 24. Ability to describe each of the six factors affecting soil loss appropriate for a given situation. & 3.45 & 3.67 & 3.42 & 3.77 & 0.79 \\
\hline 25. Ability to locate values for each of the six factors affecting soil loss appropriate for a given situation. & 3.36 & 3.53 & 3.25 & 3.46 & 0.89 \\
\hline 26. Ability to calculate soil loss from water erosion from the USLE. & 3.91 & 3.80 & 3.58 & 3.46 & 0.76 \\
\hline $\begin{array}{l}\text { 27. Ability to determine suitable values for one of the six soil loss factors if allowable loss and values } \\
\text { of the other five factors are known. }\end{array}$ & 4.09 & 3.60 & 3.58 & 3.46 & 0.61 \\
\hline $\begin{array}{l}\text { 28. Ability to describe the three types of wind erosion and describe the five factors that affect the amount } \\
\text { of soil lost by wind erosion. }\end{array}$ & 4.00 & 3.53 & 3.75 & 3.85 & 0.50 \\
\hline 29. Ability to identify particle size ranges which are susceptible to each of the three types of wind erosion. & 3.82 & 3.60 & 4.17 & 4.23 & 0.37 \\
\hline $\begin{array}{l}\text { 30. Ability to identify whether wind, water, or both kinds of erosion are likely problems when given } \\
\text { a field erosion situation. }\end{array}$ & 4.18 & 3.67 & 3.92 & 4.00 & 0.48 \\
\hline 31. Ability to select erosion control measures for a field situation. & 3.91 & 3.60 & 4.00 & 3.85 & 0.65 \\
\hline \multicolumn{6}{|l|}{ How much has this lesson added to your skills in each of the following? } \\
\hline 32. Identifying the initial signs of erosion. & 3.36 & 3.47 & 3.83 & 3.69 & 0.53 \\
\hline 33. Selecting appropriate solutions to the various types of erosion. & 3.55 & 3.60 & 3.75 & 3.77 & 0.90 \\
\hline \multicolumn{6}{|l|}{ To what extent did you make gains in the following as a result of this lesson? } \\
\hline 34. Understanding the main concepts of erosion. & 3.82 & 3.87 & 4.00 & 4.00 & 0.89 \\
\hline 35. Understanding the relationship between factors contributing to soil erosion. & 3.91 & 3.87 & 3.83 & 4.08 & 0.85 \\
\hline 36. Understanding how ideas in this lesson relate to those in other classes. & 4.09 & 4.13 & 3.75 & 4.31 & 0.78 \\
\hline 37. Understanding the relevance of this module to real world issues on erosion. & 3.82 & 3.60 & 3.58 & 3.85 & 0.88 \\
\hline 38. Appreciating soil management and conservation. & 3.82 & 3.80 & 3.92 & 3.46 & 0.69 \\
\hline 39. Ability to think through a problem or argument related to erosion. & 3.64 & 3.87 & 3.92 & 3.77 & 0.87 \\
\hline 40. Confidence in your ability to address issues and problems related to erosion. & 3.82 & 3.80 & 3.50 & 3.85 & 0.69 \\
\hline 41. Feeling comfortable with complex ideas related to erosion. & 3.45 & 3.47 & 3.67 & 3.85 & 0.62 \\
\hline 42. Enthusiasm for soil management and conservation. & 3.00 & 3.73 & 3.58 & 3.46 & 0.30 \\
\hline 43. Understanding the major components, causes, and prevention measures associated with erosion. & 3.55 & 3.60 & 3.75 & 3.77 & 0.91 \\
\hline
\end{tabular}

$\dagger$ Kolb Learning Styles Inventory category: Type I = diverger, Type II = accommodator, Type III = converger, Type IV = assimilator.

\$ Significant at 0.1 probability level.

$\S$ Response levels 1 to 5 ( 5 = best, $1=$ worst $)$. 
tive USLE model possibly contributed to similar perception among learners because it can satisfy the how, what, why, and, what if questions from different learners.

There was no difference in perceived skills gained and perceived understanding of soil erosion among students with different learning styles (Questions 19-31). The availability of this resource within the online lesson allowed students to assess the effect of their own management decisions on soil erosion. The inclusion of simulation models as an online teaching resource is especially valuable; promoting student knowledge on complex processes and thus eliminating the need to conduct complex, time consuming, and expensive experiments (MacKenzie et al., 2001).

Perceived understanding of the soil erosion process, soil erosion factors, management and environmental conditions inducing erosion, and solutions to controlling erosion were also similar among student learning style (Questions 34-43). Relevance of the lesson to real world issues, the appreciation of soil management, and student enthusiasm for soil management and conservation were similar among different learners.

\section{CONCLUSIONS}

The SALG survey found that students who have different KLSI learning styles had similar perceptions on the design of the class activities and the way the lesson was delivered. Online lessons should not be differentially attractive to one or two specific learning styles but should be attractive to all types of learners. With proper implementation of instructional design and technical support, incorporation of online lessons into soil science classes seems to be an effective way of filling the gaps created between teaching method and learning style.

\section{REFERENCES}

DeBello, T. 1990. Comparison of eleven major learning styles models: Variables, appropriate populations, validity of instrumentation, and the research behind them. J. Reading Writing Learning Disabilities International 6:203-222.

Doherty, W.A., and C.D. Maddux. 2002. An investigation of methods of in- struction and student learning styles in internet-based community college courses. p. 23-32. In C.D. Maddux et al. (ed.) Distance education: Issues and concerns. The Haworth Press, Binghamton, NY.

Donaldson, J.L., J.S. Thomson, P.R. Whittington, and N.O. Nti. 1999. Computer access, usage, and literacy of undergraduates in the agricultural sciences. NACTA J. 43:20-29.

Ellsworth, J. 1995. Using computer-mediated communication in teaching university courses. p. 29-36. In Z.L. Berge and M.P. Collins (ed.) Computermediated communication and the online classroom. Vol. 1. Hampton Press, Cresskill, NJ

Felder, R.M. 1996. Matters of style. Am. Soc. Eng. Educ. Prism. 6(4):18-23.

Felder, R.M., and B. Solomon. 1999. Learning styles and strategies [Online]. Available at www.ncsu.edu/felder-public/ILSdir/styles.htm (accessed 10 Sept. 2004; verified 21 Jan. 2005). North Carolina State Univ., Raleigh, $\mathrm{NC}$.

Frederico, P. 2000. Learning styles and student attitudes toward various aspects of network-based instruction. Comput. Human Behavior $16: 359-379$

Gravetter, F.J., and L.B. Wallnau. 1996. Statistics for the behavioral sciences. 4th ed. West Publ. Co., San Francisco, CA.

Kolb, D.A. 1976. Learning style inventory: Technical manual. McBer Co., Boston, MA.

Littell, R.C., G.A. Milliken, W.W. Stroup, and R.D. Wolfinger. 1999. SAS system for mixed models. SAS Inst., Cary, NC.

MacKenzie, J.G., W.B. Earl, R.M. Allen, and I.A. Gilmour. 2001. Amoco computer simulation in chemical engineering education. J. Eng. Educ. 90:331-345.

Mamo, M., T. Kettler, D. Husmann, and D. McCallister. 2004. Assessment of an online erosion lesson as a teaching tool in Introductory Soil Science. NACTA J. 48:47-52.

SAS Institute. 1999. SAS/STAT user's guide. Version Windows 8. SAS Inst. Inc., Cary, NC.

Seymour, E. 1997. Student assessment of learning gains (SALG). Wisconsin Center for Education Research, Univ. of Wisconsin-Madison System Board of Regents, Madison, WI.

Thien, S.J. 1999. USLE99-Universal Soil Loss Equation: Kansas version [Online]. Available at www.oznet.ksu.edu/agronomy/soils305/Software.htm (accessed 26 Mar. 2004; verified 21 Jan. 2005). Kansas State Univ., Manhattan.

U.S. Department of Education. 1995. Survey on distance education courses offered by higher education [Online]. Natl. Center Educ. Stat., Postsecondary Education Quick Information System. Available at www.ed.gov (accessed 26 Mar. 2004; verified 21 Jan. 2005). U.S. Department of Education, Washington, DC. 